\title{
Causes and Consequences of Sexual Violence in Male Prisons in Kenya: A Study of Kisumu Maximum Security Prison, Kenya
}

\author{
Martin Kelvin Inyani \\ Department of Social Work and Criminology \\ Kibabii University \\ P.O Box 1699 - 50200 BUNGOMA, KENYA
}

\begin{abstract}
Sexual violence in prisons is an area that calls for adequate attention so as to achieve positive results in the rehabilitation of offenders. Globally, regionally and locally this phenomenon has not received the much-needed attention as one of the challenges facing correctional institutions. This study investigated causes and consequences of sexual violence in Kisumu Maximum Security Prison. The study applied the Deprivation Model and Differential Association Theory to show how the inability to access and enjoy some privileges might be a cause of sexual violence in male prisons. The target population was prisoners, prison staff of Kisumu Maximum Security Prison, and Kisumu County Probation Officers. Stratified random sampling and purposive sampling were applied to obtain a sample size of 186 prison inmates, 18 prison staff and 6 Probation Officers. Questionnaires were used to collect data from prisoners while key informant guide was used on Prison Staff and Probation Officers. The collected data was analyzed using both descriptive and inferential statistics and the outputs were presented using tables, figures, and graphs. The study established that sexual violence was rampant in Kisumu Maximum Security Prisons with majority of the prisoners having knowledge of this vice and blaming congestion as a key motivator. Also, prison administration was also blamed for perpetuating the commission of sexual violence by failing to address and documenting these reports. Based on the study findings, it was recommended that increased surveillance by increasing staff and use of closed circuit cameras in the halls of residence, improved accommodation to ease congestion, introduction of supervised frequent conjugal visitations by partners, improved provision of basic necessities and lastly keeping the convicts constantly engaged in trainings and recreational activities address the problem of sexual violence in Kisumu Maximum Security Prison.
\end{abstract} Keywords: Causes, Consequences, Sexual Violence, Male Prisons

DOI: $10.7176 /$ PPAR/11-5-08

Publication date:June $30^{\text {th }} 2021$

\subsection{Background of the Study}

Prisons command a substantial amount of academic and popular attention. It is within these institutional sites that the goal of punishing criminal offenders is concentrated in modern society, (Wright \& Miller 2005:1299). The implications of sexual violence usually follow the prisoner back to the community once he/she has been released, (Wolf, Blitz, Shi, Bachman \& Siegel:2006). Prison crowding, shortage of staff and design flaws have all contributed to sexual violence, as prison staff may feel unable to protect inmates, (Carlson \& Garrett 2008:281). The common form of violence that is associated with most prisons around the world is sexual harassment and victimization, (Wolf, Blitz, Shi et al:2006).

Each year, thousands of men face sexual predation and violence while in these carceral institutions. Though the terrors of sexual violence in most of these institutions is part of most of the general public collective conscience, it is only recently that researchers have devoted considerable attention to this problem, (Bell, Coven, Cronan et al, 1999:197). Sexual offences in Prison is a complex continuum that includes those acts and behaviors that are non-consensual, and not limited to sexual assault, extortion for sex and sexual harassment, which may involve prisoners and in some cases staff as perpetrators, (Dumond, 2006:144). Studies of sexual violence in prisons carried out around the world showed varying frequency estimates, estimates of male prisoners who engage in sex with their fellow inmates ranging from 2 to $65 \%$ and of those sexually assaulted being within the range of $40 \%$. These disparities may be caused by differences in existing conditions, inmate populations and research methods in prison that affect opportunity and privacy. Researchers insist that categorizing sex in prison as either forced or consensual is often overly simplistic, (Okie 2007:107).

Sexual violence within U.S. prisons has become the forms of an unprecedented public policy discussion. The heightened focus on sexual violence in prisons has brought about more research and caused a greater sense of need to develop and enforce effective misconduct policies and practices. It has resulted in the passage of important legislations, (Carlson \& Garrett 2008:275). As the population of prisoners in correctional institutions gradually grows to high proportions in U.S., the challenge of sexual violence in these institutions continues to be there, (Dumond, 2000:408).

The prevalent high-risk behaviors in Nigeria prisons include marriages among convicts, unprotected sexual attacks, sexual bartering, forced sexual engagements, sex and sexual assault between convicts; mostly anal 
between males, (Saliu \& Akintunde, 2014). In South Africa the growing body of evidence supports the view that the problem of sexual violence in carceral institutions is widespread and in need of urgent attention, (Gear, 2010:25). In one of the studies done in the Kenyan Prisons $82.4 \%$ of the sampled respondent felt that homosexuality was rampant in the facility with $75 \%$ of the respondents having been forced and the rest $25 \%$ consenting to the practice, (Mbugua, Menganyi \& Gatutha, 2017:51).

Sexual violence in correctional institutions is a serious concern needing speedy and specified interventions to curb and reduce its social and health consequences, (Wolf, Blitz, Shi et al, 2006). Most of the challenges facing prisons center on the efficacy of the prison in achieving its stated objectives and the tremendous cost, both in economic and human terms, associated with its growth and development as the institution for punishment, (Wright \& Miller 2005:1299). Most researchers feel that living conditions in prisons of the world characterized by violence, drug addiction and alternately massive overcrowding and debilitating isolation in many instances counteracts any positive effect of rehabilitative efforts, (Wright \& Miller 2005:1299)

\subsection{Problem statement}

The prison can be viewed as an institution for detaining men against their will with imprisonment being seen as a form of punishment which entails the actual physical restraint of a person in custody. The main objective being deprivation of liberty, retribution, deterrence and rehabilitation, (Rukwaru, 2008:84-90). The Borstal Institutions Act Chapter 92 and Prisons Act Cap 90 of the Kenyan laws lists some of the functions of these correctional institutions as rehabilitation and reformation of offenders by engaging them in training, counselling and educational and professional programs as well as ensuring their successful reintegration back to the community.

Although there are no entirely accurate statistics of prisoners who are sexually violated in correctional institutions, few scholars deny that these abuses go on in prison, although they do disagree on its prevalence, (Wright \& Miller 2005:1295). In many nations there is considerable evidence of sexual violence occurring in correctional facilities, (Mbugua, Menganyi \& Gatutha 2017:46). There are a lot of risky sexual contacts in our prisons; every minute, somebody in a prison around the world is sneaking and doing something. Some are homosexuals; others on the other hand are just curious, bored, bisexual, lonely and experimenting for the first time, (Okie, 2007).

Sex between male convicts is rampant, and with poor food and tiny congested inhabitable cells the convicts are forced into engaging in these acts in exchange of special treatment, (Mugeni, 2017). The Kenya Prison Service recognized that sodomy occurs in prisons and a study carried out to establish the true nature and prevalence of the practice reveled harrowing results, (Limo, 2009). The subject of sex among men is a taboo in all of the Kenyan societies with many not willing to be drawn or even engage in that conversation but only wishing that morality will reign. Ironically these acts of male to male sexual encounters in Kenya especially in correctional facilities is so rife, fueling the spread of H.I.V, (Mugeni 2017). The study therefore sought to investigate causes and consequences of sexual violence in prisons in Kenya.

\subsection{Research Objectives}

i. To find out the causes of sexual violence in male prisons.

ii. To establish the consequences of sexual violence on victims in male prisons.

\subsection{Research Questions}

iii. What are the causes of sexual violence in male prisons?

iv. What are the consequences of sexual violence on victims in male prisons?

\subsection{Significance of the Study}

Prisons around the world have been facing numerous challenges over the years in their attempt to reform the clients who are sent to them. One of the challenges that have caught the attention of authorities and scholars is sexual violence. Sexual violence which is the use of force in an attempt to or engaging in sexual acts without another individual's consent. This study is significant as it sought to investigate the extent of sexual violence in male prisons in Kenya and brought to the public attention one of the greatest challenges in our prisons.

It exposed the causes of sexual violence in our prisons as both institutional and personal factors. It was noted that prison environment like congestion plays a role in perpetuating this menace with the deprivation of personal needs also being a factor. It assessed the interventions put in place by prisons management to curb this vice. The study also suggested to policy makers on the best practices of containing these vices thus ensuring a successful offender rehabilitation program and also significantly reducing on cases of recidivism. It also helped in establishing better treatment plans for offenders and more specifically victims of sexual violence in prisons, the study also made policy and research recommendations for addressing the challenge of sexual violence at Kisumu Maximum Security Prisons. It also suggested areas that are of interest for future research in addressing the challenges that prisoners face during their incarceration period. 


\subsection{Literature Review and Theoretical Framework}

Prison is a carceral institution meant for holding in confinement and punishing offenders who have been convicted for crimes by a competent court of law. This is done by severely restricting the freedoms enjoyed by these convicts, this helps protect the society from dangerous criminals, (World book, 2007). In Kenya the prisons department is in the Ministry of Interior and mandated to among others; offer the following services according to the Prisons Act Chapter 90 and The Borstal Institutions Act Chapter 92.

1. Containing and housing offenders in safe custody

2. Reformation and rehabilitation of the different offenders in their custody through engaging them in training, offering educational and professional programs and counselling.

3. Ensuring the justice is administered

4. Control and training of offenders who are below the ages of majority in Borstal and other institutions.

The concept of prison is in its ideas and meanings many of which inspire fear and which are deeply significant and dramatic. What comes into our minds when we talk of prison according to Rukwaru is a dwelling where convicted criminals are brought and held together in custody for purposes of punishment, Prison is indeed a very powerful psychological symbol: a place where those who have committed wrongs in the society, things that anyone of us might be pushed to do are kept apart from the larger society in order to prevent their repetition, (Rukwaru, 2008:92).

Types of prisons range from Maximum Security Prisons which generally house offenders serving longer prison sentences and have engaged in serious crimes, Medium Security Prisons, holding offenders who have been found to have committed less serious crimes and Minimum Security Prisons which are not as strict as Maximum prisons as they are holding offenders who are not considered to be dangerous and lastly Juvenile Correctional Institutions holding young offenders below 18 years who are in conflict with the law, (World Book, 2007) .

\subsubsection{Sexual violence in prisons}

Male convicts in prison spend their lives in a setting which is synonymous with danger, deprivation of basic needs and subordination. The prisoners are denied all their external worldly comforts of power and status, (Phillips, 2001:17). Research on sexual victimization in carceral institutions has been sparse. As a result, considerable debates continue to dominate discourses concerning the prevalence of prison sexual victimization, (Jones \& Pratt 2008:281). According to one of the most outstanding research on prison sexual violence, 20\% of U.S. inmates in these male institutions are usually sexually violated during their imprisonment, (Rothstein \& Stannow, 2009).

These shocking statistics do not really expose a break down in the incarceration system. Rather, sexual violence in prisons is largely blamed on mismanagement, dangerous practices and insufficient policies. For example, the vulnerable inmates are usually placed in the same cells with predators, abused persistently, and earmarked as fair targets for future attack, (Rothstein \& Stannow, 2009).

The Sexual Offences Act NO.3 of 2006 in Kenya recognizes some of the following sexual offences. These are some of the common documented forms of sexual offences rampant in prisons around the world. Rape which can be defined as the intentional and unlawful penetration of one's genital organ without consent or if consensual then the consent was derived from threats and intimidation, attempted rape which could be defined as the act of attempting to engage in unwarranted sexual acts, Sexual assault, induced indecent acts, gang rape among others.

Some cases of rape in our prisons are usually planned with others being unprompted; some focus on a target victim, while others occur as part of another offence, for example burglary. While other rapists engage in a single crime, some are perennial offenders; some attacks are committed by individuals while others engage in group or gang rapes. Some use force as a means to attack, intimidate and subdue their target, others usually prey upon those that are weakened by drugs and other abused substances, (Siegel, 2010:308).

\subsubsection{Causes of sexual violence in prisons}

Different factors have been identified as the causes of sexual violence in prisons. They include but not limited to; 1.5.2.1 Power and Control

Though widely believed that the rampant sexual violence in these carceral institutions is about sexual gratification, studies have suggested that it is more about power and control. With little ability to exert influence within these walls of these institutions; something that would have been comfortably done in public, these prisoners are forced to exercise the control over their colleagues using sex as a tool of trade, (Gear, 2010).

Masculinity to social constructionists is a continuous performance with manhood never being secured but constantly progressing. The cultural expectations then of what manhood ought to be is recouped within these walls. Cultural determinants and proscriptions guide men in strategies for building honor and avoiding humiliation at all cost. The construction of the concept of manhood in correctional institutions represents an acceptance of a setting of harsh social controls and scarce resources, (Phillips, 2001:13). Violence is an integral part of 'manhood' that anyone made a 'woman' in these prisons wants to break away from the rampant abuses 
and be elevated to manhood, it is because of this that one is pushed to commit violence among other inmates; and mostly the new ones to prove his worthiness, (Gear, 2010)

Violence of sexual nature in Prisons is intertwined in the pecking order and rites of gangs which control literally everything within those walls. Forced sexual relationships are part of the gang hierarchies, and sexual violence is usually a means of classifying new members who are joining prisons into these groups. But in as much as sexual activities are entrenched in the convicts and gang culture, the ways in which different cultures have normalized violence concurrently makes it hard to spot. Convicts who are victims of this violence in these correctional institutions shockingly are not recognized as men; both by fellow inmates and prison staff, but are usually thought to have been converted into 'women', (Gear, 2010)

\subsubsection{Prisons environment}

According to Knowles, the male prison setting allows for and even consents to sexual aggression, (Knowles, 1999:268). Various studies on this behavior has shown that aggressors usually engage several approaches to subdue their victims, including entrapment, physical force and psychological manipulation, (Dumond 2006:146). Prisoners rape others prisoners due to various reasons, including sexual gratification, extortion, creating fear among the other inmates, and to maintain power over other inmates, (Wright \& Miller 2005:1295). While others might be doing it as a survival tactic to curb with the punitive, depriving atmosphere of prison life, (Knowles, 1999:273).

In Nigeria prisons, same sex practices are rampant due to the fact that inmates sleep together in the same cell which is occasioned by overcrowding, (Saliu \& Akintunde, 2014). According to Mbugua, most inmates are not homosexuals but the prevailing circumstances due to confinement within the prisons walls which are dominated by men and absence of conjugal visits makes them engage in these activities, (Mbugua, Menganyi \& Gatutha, 2017:45). A number of researches have expounded on the role played by power and status in prison sexual violence, and many expect that these institutions holding more aggressive convicts automatically will have a higher occurrence of sexual violence, (Bell, Coven, Cronan et al, 1999:197).

In South Africa knowledge and practices of these acts in male correctional facilities are highly determined by the inmate higher on the prison hierarchy and gang cultures that exists in these correctional institutions. The behavior, practices and beliefs that sum up these practices are usually considered 'normal', and are a 'luxury' to only those power wielding prisoners. A historical assessment of prison gangs known as 'the Numbers' in South African prisons has helped to dictate prison inmate culture. Criminologists, Prison officials, Psychological practitioners, academicians and prisoners themselves believe that practices of sexual violence in these correctional institutions is motivated by power and the need for control than it is for sexual enjoyment, (Jones \& Pratt, 2008:282).

Sexual violence in the ultra-masculine world of these correctional facilities is the ultimate humiliation that a male convict can be exposed to by forcing him to assume a feminine role, (Knowles, 1999:273). Perpetrator of sexual violence in most of these correctional institutions "demonstrates physical prowess and control over other inmates" The recipient on his part is usually not considered a victim, but rather a weakling, unable to defend himself (Phillips, 2001;15). Not being 'attached' to a 'husband', inmates with a feminized identity imposed on them after constant sexual abuse by those prisoners who view them as accessible sexual materials face a myriad of challenges and greatly exposes them. Ironically these 'benefits' of the 'marriage' that exists among these inmates assist in conceptually putting a tight lid on the violence going on in prisons and exploitation on which it is predicated, (Gear, 2010:26).

\subsubsection{Status of the victims}

Certain clusters of inmates are usually more prone to sexual violence in prisons than others. These groups include those who are physically unfit, those who are suffering from illnesses, the weak, the younger offenders, those with mental issues, those not subscribing to gangs, those known to be homosexuals, convicted sex offenders, those who violate the "code of silence", those not liked by prison staff and/or other inmates, previous victims of sexual assaults among others, (Dumond 2000:408). Younger prisoners are more prone to these attacks than the groups, it is even riskier if one is serving a new conviction. Correctional institutions with a population made of younger inmates would ordinarily be expected in most cases to contribute to a higher rate of cases of sexual violence than the institutions holding more senior offenders, (Wolff, Blitz, Shi et al 2006:835).

In the United States the most sidelined inmates tend to be the most susceptible to sexual abuses. Those who are easily thought to be of a different sexual orientation for example gay, lesbians, transgender to name but a few are usually the easy targets. Whether living in correctional institutions with an adult or juvenile population, younger inmates are also usually at a much higher risk of being targeted. Inmates with disabilities whether physical or mental, or have developmental challenges are greatly at risk, (Rothstein \& Stannow, 2009).

\subsubsection{Race of the victims}

Although many reasons have been suggested to be the reasons for sexual violence in these facilities, they are overshadowed by the racial groups of the victims and the perpetrators. Prison sexual violence has been shown to be motivated by race, (Knowles, 1999). Another study in the U.S. has shown that race can play a significant role 
in victimization. In the U.S. sexual victimization among inmates has a racial 'touch', with whites being most of the reported victims and the perpetrators being black, (Wolf, Blitz, Shi et al, 2006:835).

\subsubsection{Systemic failures by the prison management}

The acceptance and tolerance of prison sexual violence by correctional staff, slow or even lack of interventions, and absence of interest in enlightening newcomers concerning such threats were thought to be the leading hindrance in the prevention of these vices, (Zweig, Naser, Blackmore et al, 2006:3). A study reported worrying trends of correctional officials not doing anything about cases of sexual violence within their facilities and that inmates' perpetrating these vices were in most cases allowed to continue with impunity, (Dumond, 2006:146). In Nigeria some prisoners are always tricked by other prison inmates to engage in sexual intercourse in exchange of meals and other basic needs which are essential in the prison, (Saliu \& Akintunde, 2014). The dire need of basic provisions present in the state of imprisonment in our correctional facilities and the need to find an alternative gratification might explain sexual violence in most of the prisons, (Knowles, 1999:271).

Most of the sexual assault victims in correctional institutions do not report these acts due to fears of reprisals from their fellow inmates, fear of not being believed by the authorities, or believe that if it is known then they might be exposed to even more dangers if not physical attacks, (Dumond, 2006:154). Most sexually abused inmates seldom have enough options for raising their assault to prison management. In some shocking cases corrections officers facilitate or even participate in sexual violence, and laugh off the inmates cries for help, and allow violators impunity. Many correctional institutions don't have mechanisms to be used to addresses these acts, instead they insist on strenuous bureaucratic procedures that makes it almost impossible for inmates to meet thus frustrating them into silence, (Rothstein \& Stannow, 2009).

To worsen the situation, apart from the fear of retaliation from correctional officers and other inmates for reporting these abuses, survivors who gather enough strength and report abuses may ironically expose themselves to disciplinary actions, for 'engaging' in prohibited sexual activity, (Rothstein \& Stannow, 2009). In many American prisons, sexual violence and rape are most of the times not accorded sufficient attention by the institutional management. The complexity of sexual violence against prisoners pervades the whole correctional system, (Bell, Coven, Cronan et al, 1999:196).

\subsubsection{Consequences of sexual violence on incarcerated victims}

Researchers contend that sexual violence in correctional institutions have contributed to a myriad of both institutional and individual 1 problems, (Jones \& Pratt 2008).

\subsubsection{Psychological harm}

Convicts (mostly men) in prison 'measure' one another by use of a wide range of external stylistic and behavioral cues. Inside the prison which in most cases is always crowded, avoiding shame and perpetual embarrassment is essential not just for survival purposes but also building an image as a strong man who can overcome any challenges, (Phillips, 2001:15). An increased loyalty among subcultures within the facility, may contribute to what is understood as the code of silence; which is an unwritten code among groups that reporting infractions, abuse or misconduct is not acceptable and if one does, he/she may face serious consequences, (Carlson \& Garrett, 2008:281). Victims of rape in these prisons are usually pushed into being at the mercy of their attackers whenever they need any sexual satisfaction from the time when they are first abused, (Knowles, 1999:267).

The complex and intimate nature of sexual violence may contribute to despair, shame, humiliation confusion and guilt within victims. Those who have been exposed to constant sexual and physical victimization, may think of suicide as the only choice, which is a major cause of deaths in prisons in the United States, (Dumond, 2006:152). The constant stigmatization of male sexual violence victims has been recorded outside the correctional institutions' walls, as are the negative consequences.

The psychological and emotional suffering which the victims go through as a result of sexual violence in prisons are often assumed by authorities while prisoners are still in these prisons wall. The scars left behind by such traumatic experiences affects the lives of these convicts once they have been released from these correctional institutions, they can also negative effect on the larger public, (Bell, Coven, Cronan, et al 1999).

Prisoner rape survivors in most cases are usually forced to endure the suffering in silence because they lack adequate resources, their personal safety is usually overlooked, and are frustrated from pursuing legal recourse. Leaving them exposed to a myriad of emotional and psychological problems including but not limited to fear, shame, memory losses among others. The lack of health care exposes the victims to high risk of having other serious challenges, which includes addiction, depression, post-traumatic stress disorder, feelings of suicide, and alcohol and drug addiction, (Rothstein \& Stannow, 2009). One study that was done in the U.S noted that many years after, $16.5 \%$ of victims of rape exhibited signs of post-traumatic stress disorder, (Dumond, 2006:151). A study done in one of the state prisons in the U.S showed that almost $80 \%$ of prisoners who encountered sexual violence experienced serious emotional harm, half of them experienced cases of depression while the remaining one-third contemplated committing suicide, (Bell, Coven, Cronan et al, 1999:203).

\subsubsection{Physical harm}


The consequences of sexual violence in prisons includes injuries occasioned by violent physical attacks, risks of acquiring sexually transmitted diseases or infections, mental effects that include post-traumatic stress disorders, rape trauma syndrome, stress response syndrome, stigmatization and repeat victimization all affecting these inmates behavioral and cognitive functioning, (Jones \& Pratt, 2008:282). losing a sense of 'manhood' and thus being a constant prey and exposed to a number of other threats and losses in future are also other challenges noted, (Phillips 2001:16). Some of these prisoners suffer physical injuries from prison sexual assault. A study conducted showed that $16 \%$ of the victims of sexual violence in carceral institutions had received physical injuries, (Bell, Coven, Cronan et al, 1999:208).

\subsubsection{Harm to society}

Researchers in the U.S. have shown that sexual violence in these facilities poses a risk to the carceral institutions both in terms of their safety and security, and have a direct correlation to more serious offences that may include murders, violence towards fellow convicts and correctional staff, and prison unrests, (Dumond, 2006:151). With sexual violence being the common challenge faced by prisoners, evidence abound indicating that many petty offenders end up becoming hardcore criminals after jail owing to the experiences they underwent behind bars, (Daily Nation Editorial, 2017).

Society also pays for sexual violence in prisons. Each year hundreds of prisoners released carry with them psychological trauma due to their experiences in prison. This increases their propensity towards violence, (Bell, Coven, Cronan et al, 1999:211). The U.S Correctional system is currently one that reintegrates convicts back to their positions, instead of being equipped to have a new start in their life, are usually so affected and hurt by these abuses that they unwillingly ventilate towards the innocent public, (Bell, Coven, Cronan et al, 1999:211).

\subsubsection{Retaliations}

Beyond the dangers that come with hitting back from correctional staff and other inmates, a number of survivors have always opted not to reveal their harrowing experiences due to the fact that the chances of being punished by prison authorities are higher, (Rothstein \& Stannow, 2009). Retaliations against those victims who report these abuses is all too common occurrence and can sometimes lead to catastrophic consequences, (Bell, Coven, Cronan et al, 1999:210). It may prevent victims from seeking help jeopardizing the nature or available forms of help that may be available if they choose to pursue that course, (Gear, 2010:30).

\subsubsection{Harm to victim's health}

Around the world the rates of HIV infections in correctional facilities and specifically prisons are way much higher compared to the outside population which is from six to fifty-five times higher than the entire population of the country. When prisoners are re-integrated back to their communities, a number pose a greater danger to the outside population as they could be a bank of HIV infections, (Mbugua, Menganyi \& Gatutha, 2017:45). In the United States in the year $20041.8 \%$ of inmates in correctional facilities tested positive of HIV, four times the estimated rate in the outside population. Estimates show that around $25 \%$ of HIV infected persons in the U.S tested each year have done time in these correctional facilities, (Okie 2007:106).

In Nigeria convicts are at specific risk for being infected with HIV due to congested facilities, unprotected sex and sexual assault, (Saliu \& Akintunde, 2014). One study conducted in Lang'ata Women's Prison and Kamiti Maximum Prison in Kenya found that shockingly $(56 \%)$ of the inmates in excess of half of the entire population were actually infected with HIV \& AIDS, (Musili \& Mbati, 2016).

\subsubsection{Legal consequences}

Lawsuits presented in courts by former convicts who were victims of sexual abuse and rapes in prison forced Human Rights groups in the United States to carry out an investigation, (Wolff, Blitz, Shi et al, 2006:835). Even with the obvious worrying impacts of sexual violence in our carceral institutions, we are yet to reach any concrete agreement regarding its prevalence, (Jones \& Pratt, 2008). In the United States sexual violence between inmates resulted in legal repercussions including arrests of even prison staff, referral for prosecution, or new sentences. With various strategies being employed by these institutions to curb this menace which includes placing perpetrators in solitary confinement, transfers, moving one to higher custodies and denial of other privileges including quality time, an eighty nine percent change in the system was recorded, (Zweig, Naser, Blackmore et al, 2006).

The despair of victims of sexual violence couldn't have been presented any better than this After the attack, a victim is exposed to tough choices which increases the feeling of despair. His reactions will dictate his stay in prison. If one opts for protective custody, he is at risk of continued labelling, increasing in stigmatization and likelihood of trauma in isolation. If he defends himself from his attackers, there is a risk of being tagged a troublemaker, being exposed to discipline by the authorities to even being denied the opportunity for parole. A choice to "hook-up" with a "protector" might help evade future attacks, but will certainly become sex slave forced to have sex with his "protector" if he sticks with the greater population, he may be exposed to attacks from his last attacker or those who know of the victimization, (Dumond, 2006:155).

\subsubsection{Theoretical Framework}


The study was be guided by the Deprivation Model and the Differential association theory.

\subsubsection{Deprivation Model}

Deprivation theorists have argued that prison subcultures are a natural reaction to the pains of imprisonment with their origin being the prison's wall, (Wright \& Miller, 2005:1294). This model believes that convicts, pushed by the irrepressible urge for sexual release, and restricted from the "normal" heterosexual outlets, engage in same sex-relations. The prevailing inmate culture entertains rape in prisons and long-term associations of intimate contacts, basically through legitimizing violence and replaying societal expectations of gender and sexuality, (Gear, 2010).

These subcultures develop on their own, away from the prison authorities creating a network of expectations in which in-mates step in and participate. The convicts are socialized into these subcultures through a process known as prisonization which is the learning of convict roles, attitudes, values and language. Although few deny that deprivations abound in prison, there is heated debate on the challenges they pose on prisoners, (Wright \& Miller, 2005:1294).

There are those homosexual men referred to as "fairies," "fags," "pansies," or "girls." Exhibiting effeminate characteristics, and are common targets by sex predators. We have "wolves" or "top men" the predators targeting fairies and younger inmates of slightly smaller stature. It is believed that the majority of wolves might be formerly heterosexual men pushed to homosexuality predation due to sexual deprivation. The sexual violence towards men in prison can be seen as a violence that is meant to change a victim into a 'woman' on the other hand approving the perpetrator's masculinity. "Once an initial rape has occurred, the legacy of the supposed loss of masculinity and enforced feminized identity is what the victim is viewed as sexual property-so paving the way for further sexual abuse", (Gear, 2010).

\subsubsection{Differential Association Theory}

Differential association theory was propounded by Edwin H. Sutherland a sociologist professor who argued that most criminals usually engage in offences based upon their constant association with others; that criminality is learnt by associating with other individuals with criminal traits (Schubert 2015) This theory gives preference to the power of social influences and learning processes (Anon 2015). Learning of social patterns whether conventional or not is a social process that occurs in groups (Macionis 1998). As Sutherland opines: "in an area where delinquency rate is high a boy who is sociable, gregarious, active, and athletic is very likely to come in contact with other boys in the neighborhood, learn delinquent behavior from them, and become a gangster; the psychopathic boy who is isolated, introverted and inert may remain at home, not become acquainted with other boys in the neighborhood and not become delinquent" (Anon 2015).

According to Macionis (1998) any person's propensity towards conformity or deviance relies on the relative frequency of association which encourages conventional behavior or norm violation. Differential association has basic principles which support its arguments, they include, delinquency is learnt, learning is as a result of social interactions, intimate groups are conducive for learning, criminal know-how is acquired through learning, views of laws dictates motives and persuasions, associations may be differentiated by duration, frequency of one's contact, priority and weight given and lastly delinquency is an expression of social needs and values but not excused all together.

\subsection{Research Methodology}

The study employed descriptive research design, which are concerned with describing the attributes of a particular individual, or of a group, (Kothari, 2014:35). This research design was appropriate since both qualitative data and quantitative data were collected. This study focused on Kisumu Maximum Security Prison which is one of the correctional institutions found in Kisumu County, one of the counties found in the former Nyanza province in the Western regions of Kenya. Kisumu County has its headquarters at Kisumu City. The county has got the other Penal Institutions, Kisumu Medium Security Prison, Kisumu Women's Prison, Kibos Maximum Security Prison and Kibos Medium Security Prison.

The study targeted both the prisons staff, probation officers, and convicted prisoners. The study population of this research was drawn from the prisoners' population of 2,000 inmates and the 62 prisons staff. This study employed probability and non-probability sampling techniques. Probability sampling technique was used in sampling the prisoners and in that case stratified random sampling. Non-probability sampling techniques was used in sampling key informants and more specifically purposive sampling. The study also utilized both primary and secondary data. Secondary data was obtained from prisons records. Primary data on the other hand was obtained by use of questionnaires and interview schedules.

Determining a sample size in a study is a matter of judgment and experience. One has to estimate in advance the scope and quality of information needed based on the issue being investigated, use of the information, data collection techniques, sampling strategy employed and intended and unintended outcomes expected from the study, (Mugenda 2013:40).

According to Kombo and Tromp (2006) a sample size of $10 \%$ to $30 \%$ is usually recommended as an 
enough representative for the entire study population. Thus, the sample size of this study was determined on the $10 \%$ for the convicted prisoners while $30 \%$ for the prisons staff and $30 \%$ of the Kisumu County probation officers

Number of prisoners $=10 \%$ of $2000=200$

Number of prisons staff $=30 \%$ of $62=19$

The prisoners were picked from the stratas; the stratas were made up of the period the prisoners have served in prison. Using a simple random sampling procedure, the 200 prisoners were picked from the stratas. My stratas were Below 20, 20-29, 30-39, 40-49, above 50, while the 19 prisons staff were selected using random sampling.

The data for the study was collected using anonymous questionnaires, interviews and review of official documents in the Prison's administration (documentary analysis). The study utilized primary and secondary sources of data; which was collected and coded in SPSS (2015). Data analysis according to Chakraborty (2012:241) involves three important steps, cleaning and organizing the data for analysis, Describing the data and testing hypotheses and models. This study employed tables, graphs, pie charts among others.

The study also used both descriptive and inferential data analysis. Descriptive data analysis, the first step in data analysis is to describe or summarize the data using descriptive statistics so as to enable the researcher to meaningfully describe a distribution of scores or measurements using a few indices or statistics, (Mugenda \& Mugenda 2003: 117-118). Inferential data analysis according to Mugenda and Mugenda (2003:131) deals with inferences about population based on results obtained from samples and concerned with determining how likely it is for the results obtained from a sample to be similar to results expected from the entire population. This included Chi-square test; a statistical technique which establishes relationship between two variables both of which are categorical in nature, (Mugenda 2003:134).

\subsection{Study Findings}

\subsubsection{Background Characteristics of Prisoners}

Respondents were asked to provide their ages and findings presented in table 1.

Table 1: Age of Respondents

\begin{tabular}{lcc}
\hline Age & Frequency & Percentage (\%) \\
\hline $18-25$ years & 32 & 17.2 \\
$26-35$ years & 65 & 34.94 \\
$36-45$ years & 61 & 32.28 \\
$46-55$ years & 18 & 09.68 \\
56 years and above & 10 & 05.38 \\
Total & $\mathbf{1 8 6}$ & $\mathbf{1 0 0 . 0}$ \\
\hline
\end{tabular}

Table 1 reveals that $34.94 \%$ of the study respondents were aged between 26 and 35 years while $32.28 \%$ were between 36 and 45 years of age. Respondents who were 56 years and above comprised $5.38 \%$ of the study. This shows that majority of respondents in male prisons in Kenya are young individuals who are in their prime age. Such a high number of youthful individuals in prison deprives the country energetic labor force that would otherwise drive the much-needed impetus in national building. Respondents were asked to state their marital status and findings presented in table 2.

Table 2: Marital Status of Respondents

\begin{tabular}{lll}
\hline Marital Status & Frequency & Percentage (\%) \\
\hline Single & 61 & 32.80 \\
Married & 53 & 28.49 \\
Separated & 41 & 22.04 \\
Divorced & 22 & 11.83 \\
Widowed & 09 & 04.84 \\
Total & $\mathbf{1 8 6}$ & $\mathbf{1 0 0 . 0}$ \\
\hline
\end{tabular}

Study results in table 2 show that majority of the study respondents $(32.8 \%)$ were single while $28.49 \%$ were married. It was also revealed based on the study findings that $22.04 \%$ of the respondents were separated before joining the institution. Respondents were asked to state their level of education and findings presented in table 3 . 
Table 3: Education Level of Respondents

\begin{tabular}{lll}
\hline Education Level & Frequency & Percentage (\%) \\
\hline No formal Education & 23 & 12.37 \\
Primary Education & 79 & 42.47 \\
Secondary Education & 64 & 34.41 \\
Tertiary Education & 08 & 04.30 \\
Trade/ Technical & 12 & 06.45 \\
Total & $\mathbf{1 8 6}$ & $\mathbf{1 0 0 . 0}$ \\
\hline
\end{tabular}

Findings in table 3 reveal that majority of the study respondents $(42.47 \%)$ had primary schools as their highest level of education followed by $34.41 \%$ whose highest level of education was secondary school.

\subsubsection{Causes of sexual violence in male prisons}

Respondents were asked to state some of the factors that might be contributing to sexual violence in prisons.

1.8.2.1 Descriptive analysis for responses to causes of sexual violence in male prisons.

Respondents were asked to state where they lived before their imprisonment and findings presented in figure 1

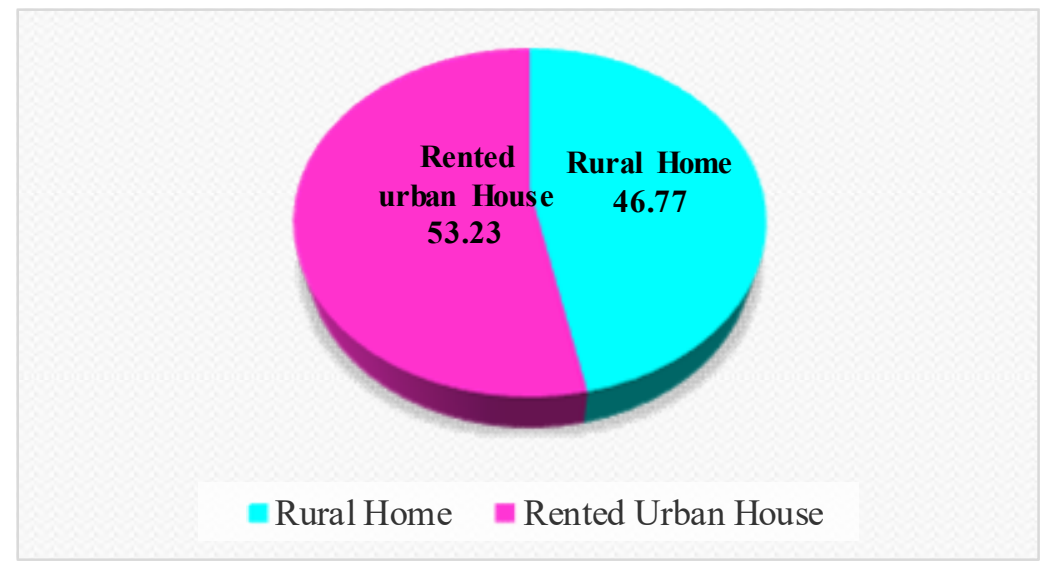

Figure 1: Residence of Respondents

Study findings in figure 1 show that $53.23 \%$ of the respondents lived in rented urban houses before incarceration while 46.775 lived their rural homes.

Respondents were asked to the state the number of years that they had been sentenced to imprisonment and findings presented in table 4.

Table 4: Length of Imprisonment

\begin{tabular}{lcc}
\hline Length of imprisonment & Frequency & Percentage (\%) \\
\hline $20-30$ years & 51 & 27.42 \\
$31-40$ years & 29 & 15.59 \\
$41-50$ years & 21 & 11.29 \\
Above 50 years & 85 & 45.70 \\
Total & $\mathbf{1 8 6}$ & $\mathbf{1 0 0 . 0}$ \\
\hline
\end{tabular}

Study findings in table 4 show that majority of the respondents (45.7\%) been sentenced to a prison sentence of more than 50 years. This is followed by $27.42 \%$ of respondents that had been sentenced to a prison term of between 20 and 30 years.

Respondents were asked to state how long they had served their sentences and findings presented in table 5 Table 5: Duration already spent in prison

\begin{tabular}{lcc}
\hline Length of imprisonment & Frequency & Percentage (\%) \\
\hline Up to 5 years & 73 & 39.25 \\
$6-11$ years & 87 & 46.77 \\
$12-17$ years & 16 & 08.60 \\
$18-23$ years & 06 & 03.23 \\
24 years or more & 04 & 2.15 \\
Total & $\mathbf{1 8 6}$ & $\mathbf{1 0 0 . 0}$ \\
\hline
\end{tabular}

Results in table 5 reveal that majority of the respondents $(46.77 \%)$ had served their sentences for 6 to 11 years while $39.25 \%$ had done a minimum of 5 years, only $2.15 \%$ of the study respondents had served their sentences for more than 24 years.

Respondents were asked to state whether they knew what sexual offences were and findings presented in 
figure 2

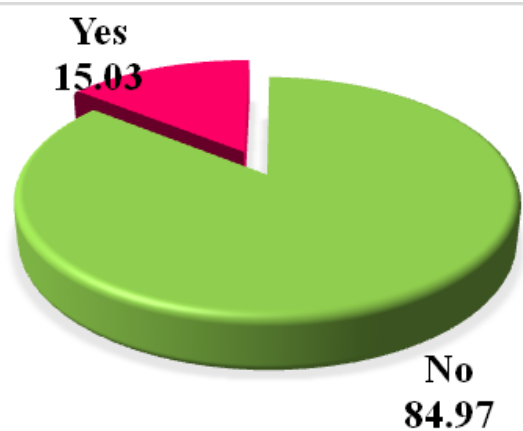

Figure 2: Respondents knowledge of Sexual Offences

Study results in figure 2 show that $84.97 \%$ of the respondents knew what sexual offences were while $15.03 \%$ did not know what sexual offences were.

Respondents were asked whether they have witnessed sexual harassment in prison and responses presented in figure 3.
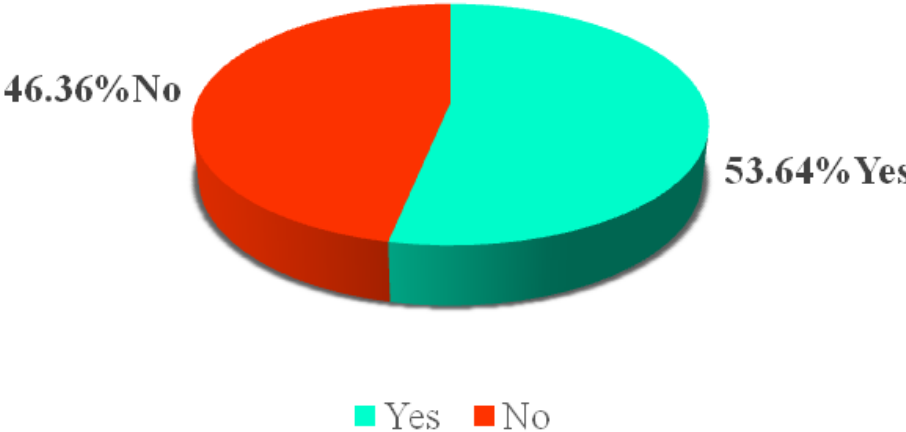

Figure 3: Whether Respondents had witnessed Sexual Violence in Prison

From findings in figure $3,53.64 \%$ of the respondents had witnessed sexual violence in prison while $43.36 \%$ of the respondents had not witnessed sexual violence in prison.

Respondents were asked if they had ever experienced sexual violence while in prison and findings presented in figure 4.

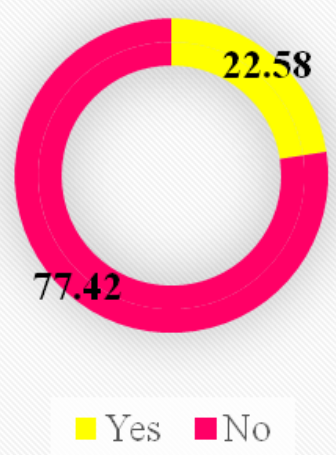

Figure 4: Whether Respondents had experienced Sexual Violence

Results in figure 4 indicate that $77.42 \%$ of the study respondents had not experienced sexual violence in prison. On the other hand, $22.58 \%$ of the respondents indicated that they had experienced sexual violence in prison.

Respondents who had experienced sexual violence in prison were asked to state the kind of sexual violence they had experienced and findings presented in figure 5 . 


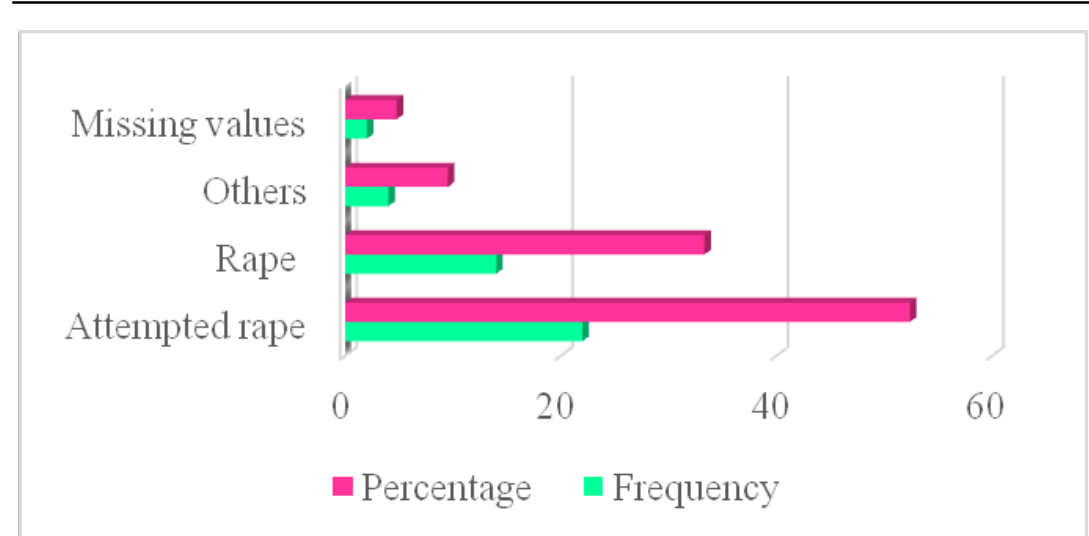

Figure 5: Type of Sexual Violence experienced

Findings in figure 5 reveal that $52.38 \%$ of the respondents who had experienced sexual violence while in prison had witnessed attempted rape while $33.33 \%$ had experienced actual rape. Further it was revealed that $9.52 \%$ of the respondents had experienced other forms of sexual violence including forced kissing, forced caressing and insertion of fingers and other objects in their private parts.

Respondents were asked how many times they had been sexually abused and findings presented in figure 6 .

40

30

20

10

0

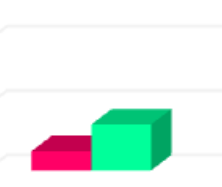

Once

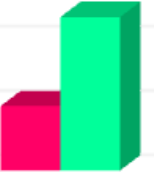

Twice

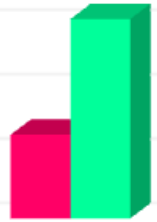

Thrice

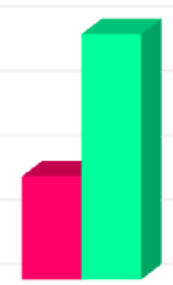

More than thrice

\section{- Frequency $\quad$ Percentage}

Figure 6: Number of times Respondents had been sexually abused

Findings in figure 6 show that $38.10 \%$ of the respondents that had been sexually violated had been violated more than thrice while $30.95 \%$ had been violated thrice. It was also established that $23.81 \%$ of the respondents had been violated twice and a further $7.14 \%$ had been violated once.

Respondents in the study were asked if they had sexually harassed others while in prison and findings presented in figure 7

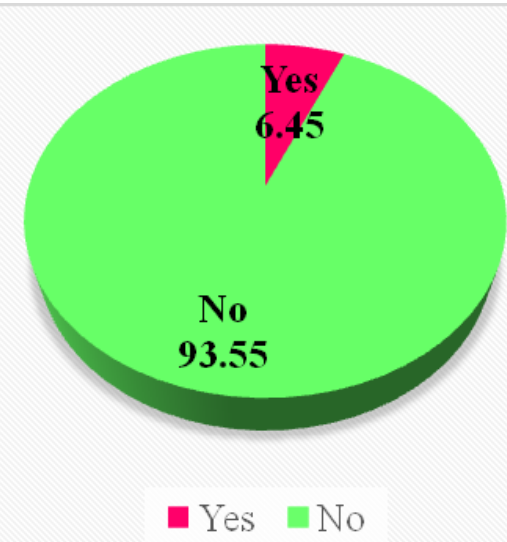

Figure 7: Whether Respondents had sexually abused others in prison

From the results in figure $7,93.55 \%$ of the respondents had not sexually abused others while in prison while $6.45 \%$ of the respondents admitted to having violated others while in prison.

Respondents were asked to state the number of times that they had sexually abused their fellow inmates and 
findings presented in table 6 .

Table 6: Number of times respondents abused others in prison

\begin{tabular}{lcc}
\hline Number of Times & Frequency & Percentage (\%) \\
\hline None & 169 & 90.86 \\
Once & 08 & 04.30 \\
Twice & 04 & 02.15 \\
Thrice & 03 & 1.61 \\
More than thrice & 02 & 01.08 \\
Total & $\mathbf{1 8 6}$ & $\mathbf{1 0 0 . 0}$ \\
\hline
\end{tabular}

From the study findings in table $6,90.86 \%$ of the respondents had not sexually abused others while in prison while 4.35 had sexually abused others once while in prison. It was also established that $2.15 \%$ of the respondents had sexually abused other twice while in prison while, $1.61 \%$ had abused others thrice and $1.08 \%$ had sexually abused others more than thrice while in prison.

Respondents were asked for their opinion regarding the major cause of sexual activities in prison and the findings presented in table 7

Table 7: Major causes of sexual activities in prison

\begin{tabular}{lcc}
\hline Cause & Frequency & Percentage (\%) \\
\hline Limited resources & 43 & 23.12 \\
Coercion & 17 & 9.14 \\
Absence of sexual partner & 74 & 39.78 \\
Administrative laxity & 19 & 10.22 \\
Consent & 33 & 17.74 \\
Total & $\mathbf{1 8 6}$ & $\mathbf{1 0 0 . 0}$ \\
\hline
\end{tabular}

Results of the study in table 7 show that $39.78 \%$ of the respondents cited absence of a sexual partner as the main cause of sexual activities in prison while $23.12 \%$ of the respondents attributed sexual activities in prison to limited resources in prison. A further $17.74 \%$ alluded to the fact that consent played an active role in the prevalence of sexual activities in prison while $9.14 \%$ indicated that coercion explained the prevalence of sexual activities in prison. Respondents were asked to state whether congestion contributed to increased sexual violence and findings presented in table 8

Table 8: Congestion and sexual violence in prison

\begin{tabular}{lll}
\hline Congestion has increased sexual violence & Frequency & Percentage (\%) \\
\hline Yes & 119 & 63.98 \\
No & 67 & 36.02 \\
Total & $\mathbf{1 8 6}$ & $\mathbf{1 0 0 . 0}$ \\
\hline
\end{tabular}

From table 8, 63.98\% of the respondents alluded to the fact that congestion increased cases of sexual violence in prison while $36.02 \%$ were of the view that congestion did not contribute to sexual violence in prison. Respondents were asked how often they received family visitations and findings presented in figure 8 .

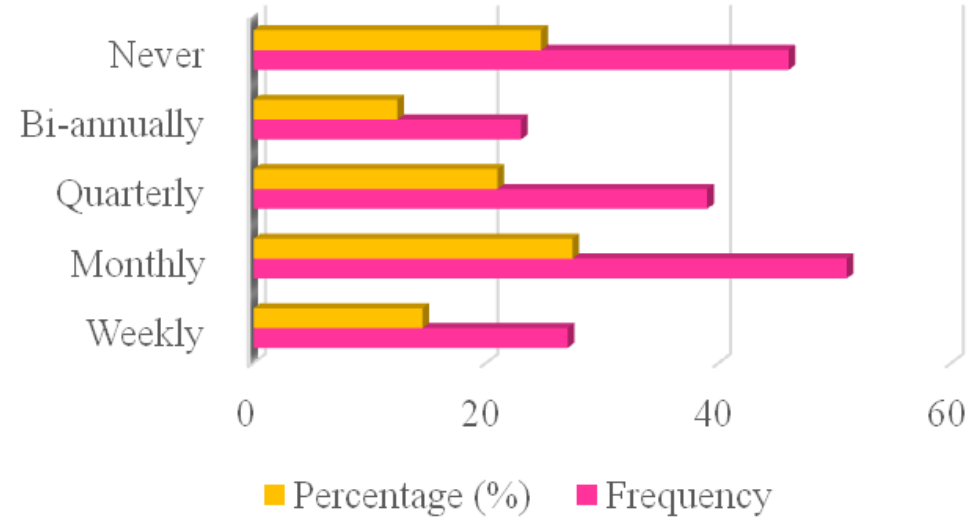

Figure 8: Family visitation while in prison

From findings in figure $8,27.42 \%$ of the respondents received family visitations monthly while $24.73 \%$ of the respondents never received family visitations at all while in prison. It was also established that $20.97 \%$ of the respondents received visitations quarterly while in prison and $14.52 \%$ were visited weekly in prison.

Respondents were asked if they got adequate time to interact with family members during visitations and 
findings presented in figure 9 .

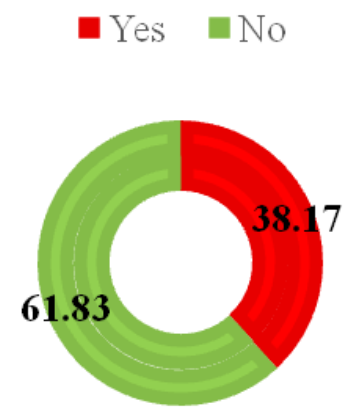

Figure 9: Adequacy of time during family visitations

From the study findings in figure 9 , it is evident that $61.83 \%$ of the respondents felt that time for family visitations was not adequate while $38.17 \%$ felt that they had adequate time during visitations.

Respondents were requested to state if they felt that visitation should be increased and findings presented in figure 10 .

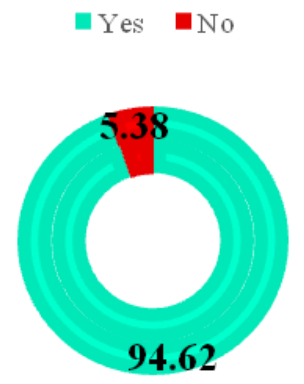

Figure 10: Whether visitations should be increased

Study results indicate that $94.62 \%$ of the respondents feel that visitation in prison should be increased while $5.38 \%$ felt that visitations should not be increased.

Respondents were asked if prison offered conjugal rights and findings presented in figure 11

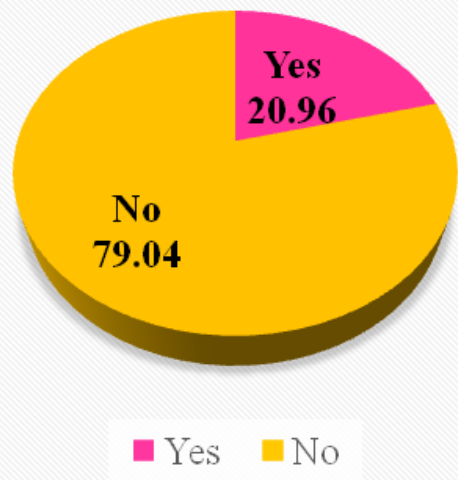

Figure 11: If Prison offered conjugal rights to inmates

Findings of the study in figure 11 reveals that $79.04 \%$ of the respondents were of the opinion that prison did not offer conjugal rights while $20.96 \%$ of the respondents alluded to the fact that they enjoyed conjugal rights in prison.

Respondents were asked if conjugal rights would help minimize cases of sexual violence in prison and findings presented in figure 12 . 


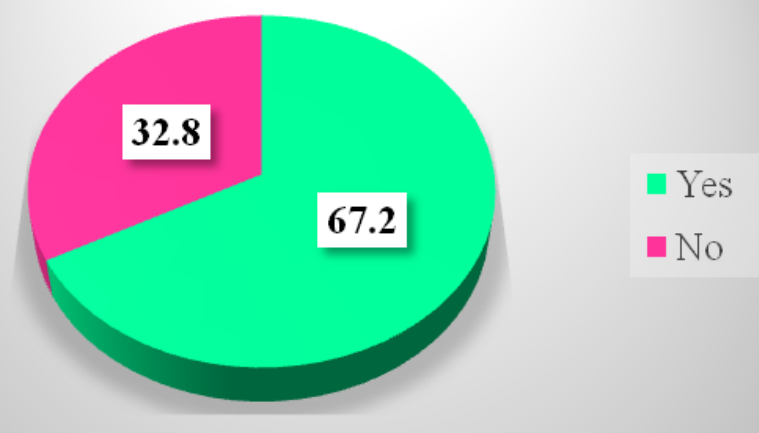

Figure 12: If conjugal rights would minimize cases of sexual violence in prison

Results of this study shows that $67.2 \%$ of the respondents indicated that conjugal rights in prison would minimize cases of sexual violence in prison while $32.8 \%$ were of the view that conjugal rights may not minimize cases of sexual violence in prison.

Respondents were asked if they felt that the government should avail facilities for conjugal rights and findings presented in figure 13 .

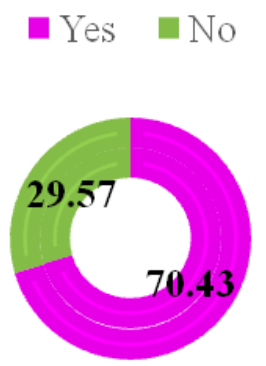

Figure 13: Government should avail facilities for conjugal rights

From the findings of the study, $70.43 \%$ of the study respondents were of the view that the government should avail facilities for enjoyment of conjugal rights in prison. On the other hand, $29.57 \%$ of the respondents were of the view that the government should not avail facilities for conjugal rights in prison.

1.8.2.2 Correlation Coefficients for individual prisoner characteristics, prison environment and power and control on sexual violence in prison

Correlation analysis was conducted between individual prisoner characteristics, prison environment and power and control and sexual violence in prison and finding presented in table 9

Table 9: Correlations coefficients for causes of sexual violence in male prisons.

\begin{tabular}{|c|c|c|c|c|c|}
\hline & & $\begin{array}{l}\text { Individual Prisoner } \\
\text { Characteristics }\end{array}$ & $\begin{array}{l}\text { Prison } \\
\text { Environment }\end{array}$ & $\begin{array}{l}\text { Power and } \\
\text { Control }\end{array}$ & $\begin{array}{l}\text { Sexual } \\
\text { Violence } \\
\text { Prison }\end{array}$ \\
\hline Individual & Pearson & 1 & & & \\
\hline \multirow[t]{2}{*}{ Characteristics } & Correlation & & & & \\
\hline & $\begin{array}{l}\text { Sig. (2-tailed) } \\
\mathrm{N}\end{array}$ & 186 & & & \\
\hline \multirow[t]{3}{*}{ Prison Environment } & $\begin{array}{l}\text { Pearson } \\
\text { Correlation }\end{array}$ & .093 & 1 & & \\
\hline & Sig. (2-tailed) & .157 & & & \\
\hline & $\mathrm{N}$ & 186 & 186 & & \\
\hline \multirow[t]{3}{*}{ Power and Control } & $\begin{array}{l}\text { Pearson } \\
\text { Correlation }\end{array}$ & $.481^{* *}$ & .494 & 1 & \\
\hline & Sig. (2-tailed) & .000 & .029 & & \\
\hline & $\mathrm{N}$ & 186 & 186 & 186 & \\
\hline \multirow{3}{*}{$\begin{array}{l}\text { Sexual Violence in } \\
\text { Prison }\end{array}$} & $\begin{array}{l}\text { Pearson } \\
\text { Correlation }\end{array}$ & $.642^{* *}$ & $.716^{* *}$ & $.501^{* *}$ & 1 \\
\hline & Sig. (2-tailed) & .000 & .000 & .000 & \\
\hline & $\mathrm{N}$ & 186 & 186 & 186 & 186 \\
\hline
\end{tabular}




\begin{tabular}{|c|c|c|c|c|c|}
\hline & & $\begin{array}{l}\text { Individual Prisoner } \\
\text { Characteristics }\end{array}$ & $\begin{array}{l}\text { Prison } \\
\text { Environment }\end{array}$ & $\begin{array}{l}\text { Power and } \\
\text { Control }\end{array}$ & $\begin{array}{l}\text { Sexual } \\
\text { Violence } \\
\text { Prison }\end{array}$ \\
\hline Individual & Pearson & 1 & & & \\
\hline \multirow[t]{2}{*}{ Characteristics } & Correlation & & & & \\
\hline & $\begin{array}{l}\text { Sig. (2-tailed) } \\
\mathrm{N}\end{array}$ & 186 & & & \\
\hline \multirow[t]{4}{*}{ Prison Environment } & Pearson & .093 & 1 & & \\
\hline & Correlation & & & & \\
\hline & Sig. (2-tailed) & .157 & & & \\
\hline & $\mathrm{N}$ & 186 & 186 & & \\
\hline \multirow[t]{3}{*}{ Power and Control } & $\begin{array}{l}\text { Pearson } \\
\text { Correlation }\end{array}$ & $.481^{* *}$ & .494 & 1 & \\
\hline & Sig. (2-tailed) & .000 & .029 & & \\
\hline & $\mathrm{N}$ & 186 & 186 & 186 & \\
\hline \multirow{3}{*}{$\begin{array}{l}\text { Sexual Violence in } \\
\text { Prison }\end{array}$} & Pearson & $.642^{* *}$ & $.716^{* *}$ & $.501^{* *}$ & 1 \\
\hline & $\begin{array}{l}\text { Correlation } \\
\text { Sig. (2-tailed) }\end{array}$ & .000 & .000 & .000 & \\
\hline & $\mathrm{N}$ & 186 & 186 & 186 & 186 \\
\hline
\end{tabular}

**. Correlation is significant at the 0.05 level (2-tailed).

Source: Research Data (2019)

A correlation coefficient statistic that describes the degree of linear association between individual prisoner characteristics, prison environment, power and control and sexual violence in prison was done and the findings of the study indicated a statistically significant relationship between prisoner individual characteristics and sexual violence $(\mathrm{r}=.642 ; \mathrm{P}<0.05)$. This implies that prisoner individual characterises significantly contribute to sexual violence in prison. It was also revealed based on the study findings that prison environment significantly influenced sexual violence in prison $(\mathrm{r}=.716 ; \mathrm{P}<0.05)$. This implies that the confinement that is characteristic of the prison environment together with sexual deprivation significantly increase the likelihood of occurrence of sexual violence in prison. Further still, the study revealed that power and control had a significant relationship with sexual violence in prison. These results relate to previous studies done by scholars who found that individual prisoner characteristics, prison environment and power and control relate with sexual violence in prison. Empirical studies have demonstrated that a certain cluster of inmates are usually more prone to sexual violence in prisons than others. These groups include those who are physically unfit, those who are suffering from illnesses, the weak, the younger offenders, those with mental issues, those not subscribing to gangs, those known to be homosexuals, convicted sex offenders, those not liked by prison staff and/or other inmates, previous victims of sexual assaults among others, (Dumond 2000).

A study by Wolff, Blitz, Shi et al. (2006) revealed that younger prisoners are more prone to these attacks than the groups, it is even riskier if one is serving a new conviction. Correctional institutions with a population made of younger inmates would ordinarily be expected in most cases to have a higher rate of cases of sexual violence than the institutions holding more senior offenders,

In the United States the most sidelined inmates tend to be the most susceptible to sexual abuses.

A study by Knowles, (1999:272) revealed that number of challenges in the prison environment among them being inadequate work opportunities, minimal trainings and recreational activities has left prisoners with excess time on their hands doing nothing but idling around, lack of privacy and limited communication with the world outside these institutions' walls reduces the ability for one to associate with the accepted intimacy practices of the society, The situation is made worse in some institutions, where the environment these convicts are in is nothing closer to one that is suitable for rehabilitation but rather a conducive state for sexual chaos, (Bell, Coven, Cronan et al, 1999:196).

Results from a study by Gear (2010) revealed that even though widely believed that the rampant sexual violence in carceral institutions is about sexual gratification, it is more about power and control. With little ability to exert influence within these walls of these institutions; something that would have been comfortably done in public, these prisoners are forced to exercise the control over their colleagues using sex as a tool of trade. 1.8.2.3 Regression analysis with Prisoner Characteristics, Prison Environment and Power and control as predictors of sexual violence in Prison.

The results for regression analysis with individual prisoner characteristics, prison environment and power and control as predictors of sexual violence in Prison are presented in table 10. 
Table 10: Model Summary for Prisoner Characteristics, Prison Environment and Power and control as predictors of sexual violence in Prison.

\begin{tabular}{llllll} 
Model & R & R Square & Adjusted R Square & Std. Error of the Estimate & Durbin-Watson \\
\hline 1 & $.353^{\mathrm{a}}$ & .379 & .372 & .86210 & 1.798
\end{tabular}

a. Predictors: (Constant), Prisoner Characteristics, Prison Environment, Power and control

b. Dependent Variable: Sexual Violence in Prison

Source: Research Data (2019)

From the table 10, the value of $\mathrm{R}$ squared was 0.379 implying that Prisoner Characteristics, Prison Environment and Power and control account for $37.9 \%$ of variance in sexual violence in prison.

1.8.2.4 ANOVA results for Prisoner Characteristics, Prison Environment and Power and control as predictors of sexual violence in Prison.

Analysis of Variance for the linear model is presented in Table 11.

Table 11: ANOVA for Prisoner Characteristics, Prison Environment and Power and control and sexual violence in Prison.

\begin{tabular}{lllllll}
\hline Model & & Sum of Squares & Df & Mean Square & F & Sig. \\
\hline 1 & Regression & 25.799 & 1 & 25.799 & 32.482 & $.000^{\mathrm{a}}$ \\
& Residual & 220.737 & 297 & .743 & & \\
& Total & 246.536 & 298 & & & \\
\hline
\end{tabular}

a. Predictors: (Constant), Prisoner Characteristics, Prison Environment, Power and control

b. Dependent Variable: Sexual Violence in Prison

Source: Research Data (2019)

ANOVA for the linear model presented in Table 11 of individual prisoner characteristics, prison environment, power and control and sexual violence in prison has an $\mathrm{F}$ - value $=32.482$ which is significant at $99 \%$ confidence level with $\mathrm{p}$ value $=0.000$ meaning that the overall model was significant in predicting sexual violence in prison.

1.8.2.5 Coefficients results for Prisoner Characteristics, Prison Environment and Power and control and sexual violence in Prison.

The Coefficients for prisoner characteristics, prison environment and power and control as predictors of sexual violence in Prison are presented in table 12.

Table 12: Coefficients Prisoner Characteristics, Prison Environment and Power and control as predictors of sexual violence in Prison.

\begin{tabular}{|c|c|c|c|c|c|c|c|c|}
\hline \multirow[b]{2}{*}{ Model } & & \multicolumn{2}{|c|}{$\begin{array}{l}\text { Unstandardized } \\
\text { Coefficients }\end{array}$} & $\begin{array}{l}\text { Standardized } \\
\text { Coefficients }\end{array}$ & \multirow[b]{2}{*}{$\mathrm{T}$} & \multirow[b]{2}{*}{ Sig. } & \multicolumn{2}{|c|}{$\begin{array}{l}\text { Collinearity } \\
\text { Statistics }\end{array}$} \\
\hline & & $\mathrm{B}$ & Std. Error & Beta & & & Tolerance & VIF \\
\hline 1 (Constant) & & 3.617 & .244 & & 11.432 & .000 & & \\
\hline $\begin{array}{l}\text { Factors of } \\
\text { Violence }\end{array}$ & Sexual & .453 & .058 & .371 & 5.688 & .000 & 1.000 & 1.000 \\
\hline
\end{tabular}

a. Dependent Variable: Sexual Violence in Prison.

Source: Research Data (2019)

Multicollinearity was measured by variance inflation factor (VIF) (tolerance) as seen in table 12 above. Variance inflation factor refers to where independent variables are highly correlated with value $>10$ hence leading to multicollinearity problem. The VIF value in the table is 1.000 hence less than 10, implying absence of multicollinearity problem. Analysis of the regression model coefficients shows there is a positive beta coefficient of 0.453 for prisoner characteristics, prison environment and power and control and sexual violence in Prison with a p-value $=0.000$ which is highly significant within $99 \%$ confidence interval. This implies that individual prisoner characteristics, prison environment and power and control significantly contribute to sexual violence in Prison.

\subsubsection{Analysis of interview schedules on causes of sexual violence}

All respondents had heard about sexual violence in prison and most commonly reported forms of sexual abuse in prison included rape, attempted rape and unwanted sexual advances including attempted kissing, caressing and insertion of fingers and other objects in the anus.

Interviews with correctional officers revealed that some of the challenges reported by prisoners included unfavourable living conditions characterised by overcrowding, inadequate personal space, inadequate meals, routine activities, sexual violence, physical violence, lack of legal assistance, lack of access to health services when needed.

1.8.2.7 Consequences of sexual violence on victims.

Respondents were questioned on whether they have had health concerns after sexually abusing or being sexually 
abused while in prison and findings presented in figure 14.

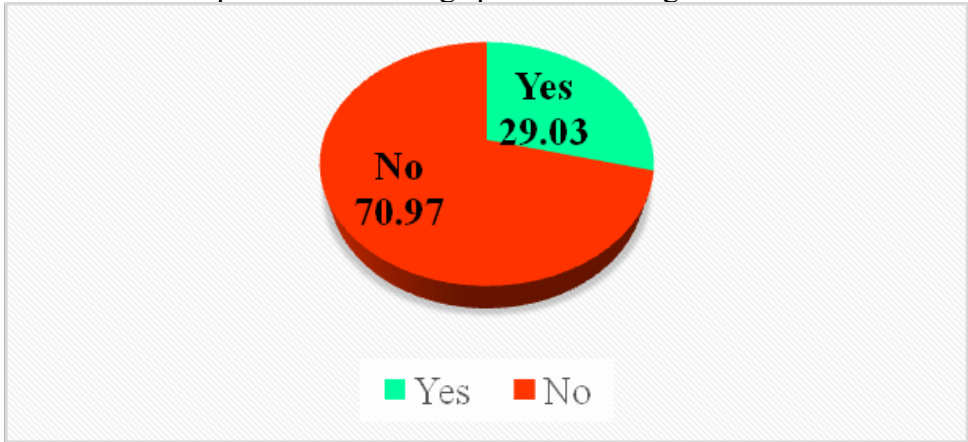

Figure 14: Health concerns after sexual violence

Findings in figure 14 show that $29.03 \%$ of the respondents reported health concerns after sexually abusing or being sexually abused while in prison. It was also observed that $70.97 \%$ of the respondents did not experience health concerns resulting from sexual violence while in prison.

Respondents were asked if they have had psychological challenges after sexually abusing or being sexually abused while in prison and findings presented in figure 15

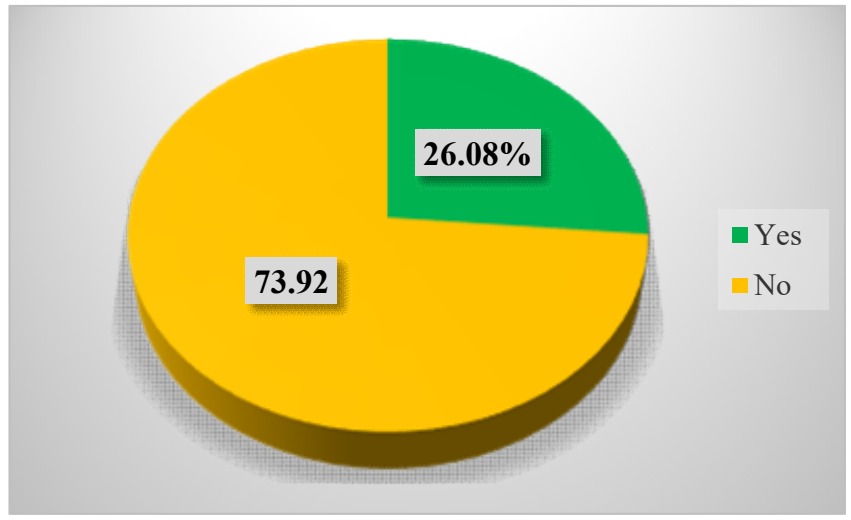

Figure 15: Psychological challenges resulting from sexual violence in prison

Results in figure 15 show that $73.92 \%$ of the respondents indicated that they did not experience psychological challenges arising from sexual violence in prison while $26.08 \%$ of the respondents reported experiencing psychological challenges arising from sexual violence in prison.

Respondents were asked whether they have had any social challenges after sexually abusing or being sexually abused while in prison and findings presented in figure 16

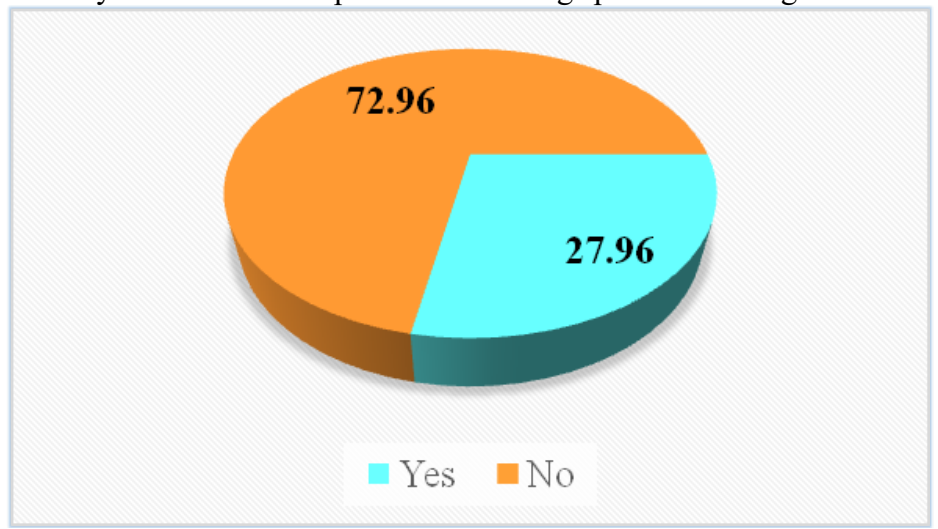

Figure 16: Social challenges arising from sexual violence in prison

From study results in figure $16,72.96 \%$ of the respondents did not experience any social challenges arising from sexually abusing or being sexually abused while in prison. On the other hand, $27.96 \%$ of the respondents reported experiencing social challenges arising from sexually abusing or being sexually abused while in prison.

Respondents were asked if they have ever felt like revenging after being sexually abused while in prison and findings presented in figure 17 


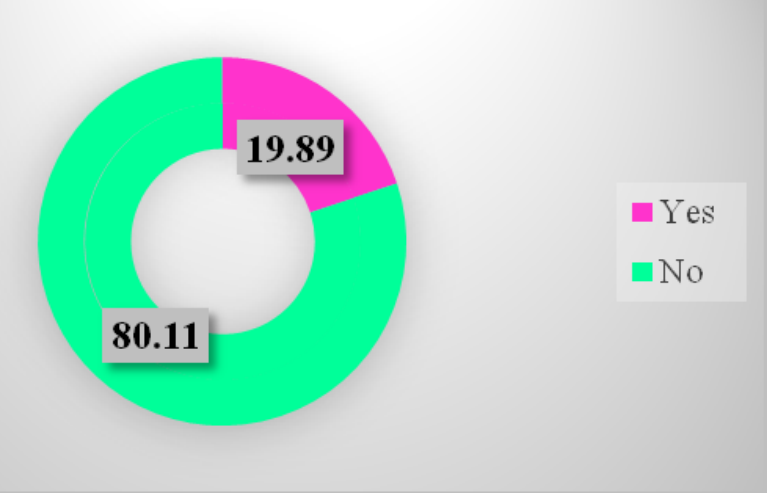

Figure 17: Revenge after sexual abuse in prison

Results in figure 17 show that $19.89 \%$ of the respondents felt like revenging as a result of being sexually abused while in prison while $80.11 \%$ did not feel like revenging.

Respondents who felt like revenging after being sexually being abused were asked if they agreed that their urge to revenge could encourage them to commit further crimes after release from prison and findings presented in table 13 .

Table 13: Urge to revenge and future criminal offences

\begin{tabular}{lcc}
\hline $\begin{array}{l}\text { If revenge would encourage committing further } \\
\text { offences after release }\end{array}$ & Frequency & Percentage (\%) \\
\hline I Strongly Agree & 19 & 10.22 \\
I Agree & 13 & 6.99 \\
Neutral & 56 & 30.11 \\
I Disagree & 46 & 24.73 \\
I strongly Disagree & 52 & 27.96 \\
Total & $\mathbf{1 8 6}$ & $\mathbf{1 0 0 . 0}$ \\
\hline
\end{tabular}

Results in table 13 reveal that $30.11 \%$ of the respondents were neutral in their response to the question whether the urge to revenge after being sexually abused while in prison could encourage them to commit further crimes after release from prison. The study also observed that $27.96 \%$ of the respondents strongly disagreed that the urge to revenge after being sexually abused while in prison could encourage them to commit further crimes after release from prison while $10.22 \%$ of the respondents strongly agreed.

Respondents were asked what could be done to prevent violence in prison and findings presented in table 14.

Table 14: Prevention of sexual violence in prison

\begin{tabular}{lcc}
\hline Prevention of sexual violence in prison & Frequency & Percentage (\%) \\
\hline Segregation & 27 & 14.52 \\
Stiffer penalties & 21 & 11.29 \\
Increased surveillance & 102 & 54.84 \\
Other measures & 36 & 19.35 \\
Total & $\mathbf{1 8 6}$ & $\mathbf{1 0 0 . 0}$ \\
\hline
\end{tabular}

Findings in table 14 shows that majority of the respondents $(54.84 \%)$ were of the view that increased surveillance in prison could prevent sexual violence while $19.35 \%$ of the respondents advocated for other measures that may be employed in preventing sexual violence in prison including providing more room for accommodation, sleeping while lights are on and sleeping in glass cubicles where everyone can see what was going on.

\subsubsection{Correlation Coefficients for the consequences of sexual violence on victims.}

Correlation analysis was done to determine the consequences of sexual violence in prison and finding presented in table 15 
Table 15: Correlations Coefficients for consequences of sexual violence on victims.

\begin{tabular}{|c|c|c|c|c|c|}
\hline & & $\begin{array}{l}\text { Sexual Violence in } \\
\text { Prison }\end{array}$ & $\begin{array}{l}\text { Physical } \\
\text { Health }\end{array}$ & $\begin{array}{l}\text { Psychological } \\
\text { Health }\end{array}$ & $\begin{array}{l}\text { Social } \\
\text { Challenges }\end{array}$ \\
\hline Sexual Violence in & Pearson & 1 & & & \\
\hline \multirow[t]{3}{*}{ Prison } & Correlation & & & & \\
\hline & Sig. (2-tailed) & & & & \\
\hline & $\mathrm{N}$ & 186 & & & \\
\hline \multirow[t]{4}{*}{ Physical Health } & Pearson & .122 & 1 & & \\
\hline & Correlation & & & & \\
\hline & Sig. (2-tailed) & .615 & & & \\
\hline & $\mathrm{N}$ & 186 & 186 & & \\
\hline \multirow{4}{*}{$\begin{array}{l}\text { Psychological } \\
\text { Health }\end{array}$} & Pearson & $.674^{* *}$ & .299 & 1 & \\
\hline & Correlation & & & & \\
\hline & Sig. (2-tailed) & .000 & .029 & & \\
\hline & $\mathrm{N}$ & 186 & 186 & 186 & \\
\hline \multirow[t]{4}{*}{ Social Challenges } & Pearson & $.586^{* *}$ & .394 & $.401^{* *}$ & 1 \\
\hline & Correlation & & & & \\
\hline & Sig. (2-tailed) & .000 & .000 & .000 & \\
\hline & $\mathrm{N}$ & 186 & 186 & 186 & 186 \\
\hline
\end{tabular}

**. Correlation is significant at the 0.05 level (2-tailed).

Source: Research Data (2019)

Study findings in table 15 reveal a statistically significant relationship between sexual violence and physical health $(\mathrm{r}=.615 ; \mathrm{P}<0.05)$. This implies that prisoners who abused or were abused by others reported physical health problems resulting from such sexual contacts while in prison. Study findings also revealed a significant relationship between sexual violence in prison and psychological health of inmates $(\mathrm{r}=.674 ; \mathrm{P}<0.05)$. This implies that inmates who reported having been abused sexually while in prison also reported psychological health challenges. It was further revealed based on the study findings that a significant relationship existed between sexual violence and social challenges among inmates $(\mathrm{r}=.586 ; \mathrm{P}<0.05)$. This implies that respondents who were involved in sexual violence experienced social isolation from other inmates in prison. Study results conform to results from previous studies on the influence of sexual violence on the health of inmates.

Jones and Pratt (2008) revealed that the consequences of sexual violence in prisons includes injuries occasioned by violent physical attacks, risks of acquiring sexually transmitted diseases or infections, mental effects that include post-traumatic stress disorders, rape trauma syndrome, stress response syndrome, stigmatization and repeat victimization all affecting these inmates behavioral and cognitive functioning, losing a sense of 'manhood' and thus being a constant prey and exposed to a number of other threats and losses in future are also other challenges noted.

A study by Bell, Coven, Cronan, et al (1999) revealed that the psychological and emotional suffering which the victims go through as a result of sexual violence in prisons are often assumed by authorities while prisoners are still in these prisons wall. The scars left behind by such traumatic experiences affects the lives of these convicts once they have been released from these correctional institutions, they can also negative effect on the larger public. Such prisoner rape survivors are in most cases forced to endure the suffering in silence because they lack adequate resources, their personal safety is usually overlooked, and are frustrated from pursuing legal recourse.

Around the world the rates of HIV infections in correctional facilities and specifically prisons are way much higher compared to the outside population which has prevalence ranging from six to fifty-five times higher than the entire population. When prisoners are re-integrated back to their communities, a number pose a greater danger to the outside population as they could be a bank of HIV infections, (Mbugua, Menganyi \& Gatutha, 2017:45).

1.8.2.9 Regression Analysis for the consequences of sexual violence on victims.

The results for regression analysis with sexual violence as a predictor for the physical health, psychological health and social challenges among inmates was done and results presented in table 16 .

Table 16: Model Summary for the consequences of sexual violence on victims.

\begin{tabular}{llllll}
\hline & & & & Std. Error & of \\
Model & $\mathrm{R}$ & R Square & Adjusted R Square & Estimate & Durbin-Watson \\
\hline 1 & $.442^{\mathrm{a}}$ & .268 & .259 & .80451 & 1.787 \\
\hline
\end{tabular}

a. Predictors: (Constant), Sexual violence in Prison

b. Dependent Variable: Physical Health, Psychological Health, Social Challenges

Source: Research Data (2019) 
Study findings in table 16 reveal an R squared value of 0.268 which implies that sexual violence accounts for $26.8 \%$ of the variance in health challenges among inmates in prison.

1.8.2.10 ANOVA results for the consequences of sexual violence on victims.

Table 17: ANOVA results for the consequences of sexual violence on victims.

\begin{tabular}{lllllll}
\hline Model & & Sum of Squares & Df & Mean Square & F & Sig. \\
\hline 1 & Regression & 48.089 & 1 & 41.331 & 69.419 & $.000^{\mathrm{a}}$ \\
& Residual & 198.447 & 297 & .684 & & \\
& Total & 246.536 & 298 & & & \\
\hline
\end{tabular}

a. Predictors: (Constant), Physical Health, Psychological Health, Social Challenges.

b. Dependent Variable: Sexual Violence

Source: Research Data (2019)

ANOVA for the linear model presented in Table 17 where sexual violence in prison was used to predict physical health, psychological health and social challenges of inmates in prison had an F - value 69.419 which was significant at $99 \%$ confidence level with $\mathrm{P}$ value $=0.000$ signifying that the overall model was significant in predicting the impact of sexual violence in prison.

1.8.2.11 Coefficients for the consequences of sexual violence on victims.

The Coefficients for the impact of sexual violence in prison are presented in table 18. Table 18: Coefficient for the consequences of sexual violence on victims.

\begin{tabular}{|c|c|c|c|c|c|c|c|c|}
\hline \multirow{2}{*}{\multicolumn{2}{|c|}{ Model }} & \multicolumn{2}{|c|}{$\begin{array}{l}\text { Unstandardized } \\
\text { Coefficients }\end{array}$} & \multicolumn{3}{|c|}{$\begin{array}{l}\text { Standardized } \\
\text { Coefficients }\end{array}$} & \multicolumn{2}{|c|}{ Collinearity Statistics } \\
\hline & & B & Std. Error & Beta & $\mathrm{T}$ & Sig. & Tolerance & VIF \\
\hline 1 & (Constant) & .598 & .129 & & 6.154 & .000 & & \\
\hline & Sexual Violence & .434 & .053 & .421 & 7.119 & .000 & 1.000 & 1.000 \\
\hline
\end{tabular}

a. Dependent Variable: Sexual violence in prison

Source: Research Data (2019)

Multicollinearity was measured by variance inflation factor (VIF). Where Variance inflation factor value $>$ 10 it implies that the independent variables of the study are highly correlated hence leading to multicollinearity problem. The VIF value in the table is less than 10 hence there is no multicollinearity problem. An analysis of the regression model coefficients shows that there is a beta co-efficient of 0.434 for sexual violence in prison with a P-value $=0.000$ which is highly significant.

\subsection{Conclusions}

The first objective sought to find out the causes of sexual violence in male prisons. The findings revealed significant relationships between individual prisoner characteristics, prison environment, power and control and sexual violence in in Kisumu Maximum prison. Regression analysis revealed significant results for prisoner characteristics, prison environment and power and control as predictors of sexual violence in male prisons in Kenya. Based on the study findings, a conclusion is made that individual prisoner characteristics, prison environment, power and control significantly influence sexual.

The second objective was to investigate the consequences of sexual violence in male prisons in Kenya. Study findings revealed a statistically significant relationship between sexual violence and physical health, psychological health and social challenges among inmates in Kisumu Maximum Prison. Regression analysis results revealed an $\mathrm{R}$ squared value that was statistically significant in predicting the impact of sexual violence. With respect to these findings, it is concluded that sexual violence significantly impacts on physical health, psychological health and social well-being of inmates in male prisons in Kenya.

Respondents were of the view that prison was not adequately equipped to handle cases of sexual violence in prison since there was no policy document on what should happen should such cases be reported.

Respondents were of the view that prison administration can do better in managing cases of sexual violence by developing policy guidelines on the stems to follow in detecting, investigating, punishing perpetrators and assisting victims of sexual violence in prison.

Regarding the study findings, a conclusion is made that prison administration, infrastructural design and prison overcrowding are factors that would curb sexual violence in prison if well implemented.

\subsection{Recommendations}

This study revealed that male convicts in prison spend their lives in a setting which is synonymous with danger, deprivation of basic needs and subordination. These offenders are denied all their external worldly comforts of power and status. Male prison setting allows for and even consents to sexual aggression due to congestion, lack of conjugal rights and scarcity or resources. Based on this finding, it is recommended that prison administration facilitates the proper housing of convicts by ensuring that they get rid of the rampant congestions, conjugal visitations should be facilitated and opportunities created to break boredom such as providing for adequate work 
opportunities, trainings and recreational activities that would keep prisoners busy and avoid evil thoughts. There is also need to ensure adequate lighting and accommodation space to reduce overcrowding that has been significantly associated with sexual violence. Surveillance needs to be increased by having more officers patrolling the halls of accommodation and the installation of closed-circuit televisions to have the facilities being monitored round the clock.

Prison administration needs to take up allegations of prison sexual violence very seriously, intervene quickly where cases are reported and enlighten newcomers concerning such threats as a way to discourage and minimize sexual violence in male prisons. There is evidence from literature that most of the sexual assault victims in correctional institutions do not report these acts due to fears of reprisals from their fellow inmates, fear of not being believed by the authorities, or believe that if it is known then they might be exposed to even more dangers if not physical attacks. Most sexually abused inmates seldom have enough options for raising their assault to prison management. It is recommended that prison administration takes up reports on sexual violence seriously and bring perpetrators to book as a measure to curb sexual violence.

This study found that victims of sexual violence experience physical and psychological health challenges. Prisoner rape survivors in most cases are usually forced to endure the suffering in silence because they lack adequate resources, their personal safety is usually overlooked, and are frustrated from pursuing legal recourse, leaving them exposed to a myriad of emotional and psychological problems including but not limited to fear, shame, memory losses among others. It is recommended that medical assistance as well as counselling services be availed to victims of sexual violence in these facilities. Where possible, victims should be provided with legal assistance to seek help from courts as a measure to deter sexual violence in prison. In addition, prison administration should address the challenge of overcrowding in the cells, keeping the inmates occupied by engaging them in an array of activities, engaging the offenders in education forums, timely health services to the victims, guiding and counselling services.

\section{REFERENCES}

Anon

2015

Differential

association.

Available

at http://www.d.umn.edu/ $\neg$ bmork/2306/Theories/BAMdiffassn.htm

Bell C., Coven M., Cronan J., Garza C., Guygemos J., \& Storto 1. (1999) Rape and Sexual Misconduct in the Prison System. Analyzing Americas most “open” secret. 18 YALE L. \& POL’Y REV.

Borstal Institutions Act Cap 92, Government Printers. Nairobi, Kenya.

Carlson P. \& Garrett J. (2008) Prison and Jail Administration (Practice and Theory) $2^{\text {nd }}$ ed. Jones and Barlett Publishers. Massachusetts U.S.A

Chakraborty, D. 2012. Research methodology. New Delhi, India.

Cooper, D. R, \& Schindler, P.S. (2003), Business Research Methods, ( $8^{\text {th }}$ edn.) U.S.A, McGraw Hill.

Denscombe, M. (2010), The good research guide for small-scale social research projects $\left(4^{\text {th }}\right.$ edn.) New York, U.S.A. McGraw Hill.

Dumond, R. (2000) Inmate sexual assault; the plague that persists. The Prison Journal, 80 (4), 407-414.

Dumond, R. (2006) "Impact of Prisoner Sexual Violence: Challenges of Implementing Public Law 108-79 the Prison Rape Elimination Act of 2003, The;Symposium," Journal of Legislation: Vol. 32: Iss. 2, Article 2. Available at:http://scholarship.law.nd.edu/jleg/vol32/iss $2 / 2$

Egessa, R., Alala, B. \& Maniagi, M. Determinants of dividend payout policy among financial firms on the Nairobi securities exchange, Kenya. https//www.researchgate.net/publication/297761835

Engel, R. \& Schutt, R. 2009. The practice of research in social work ( $2^{\text {nd }}$ edn.) Sage.

Field, A. (2009), Discovering statistics using SPSS. $3^{\text {rd }}$ Edition, Sage Publications Ltd, London.

Gear S. (2010) Imprisoning men in violence; Masculinity and sexual abuse: A view from South African Prisons. Rothstein.

Gray, D. 2004. Doing research in the real world. London. sage

Jones T. \& Pratt T. (2008) The prevalence of sexual violence in prison. International journal of offender therapy and comparative criminology, 52, 280-295

Knowles, G. (1999) Male prison rape: A search for causation and prevention. The Howard Journal, 38 (3), $267-$ 282

Kombo D. \& Tromp D, (2006) Proposal and Thesis Writing: An introduction. Pauline's Publishers Africa, Nairobi.

Kothari C \& Gaurav G. (2014) Research Methodology, Methods and Techniques, (3 ${ }^{\text {rd }}$ edn.) New Age International Publishers, New Delhi India.

Limo Lucianne (2009) Prisons turn into dens of sodomy. The Standard Newspaper, 15 $5^{\text {th }} / \mathrm{July} / 2009$, www.standard.co.ke/article/1144019275/prisons-turn-into-dens-of-sodomy.

Maciniosis J. (1998) Society, the basics (4 ${ }^{\text {th }}$ edn.) Prentice Hall, New Jersey. U.S.A.

Mbugua R, Menganyi L \& Gatutha R. (2017) High risk sexual behavior and HIV knowledge among male 
inmates: A cross sectional study in Nakuru G.K. Prison, Kenya. EPH - International journal of Medical and Health Science. Vol.3 Issue 9 ISSN 2456-6063.

Mugenda, A. 2013. Qualitative research methods, introduction. Nairobi, Kenya. Applied research \& training services

Mugenda, O \& Mugenda, A. 2003. Research methodology, quantitative \& qualitative approach. Nairobi, Kenya. Acts

Mugeni Heminigilder. (2017) Kenyan gay inmates in need of condoms to curb HIV infections https://citizentv.co.ke/news/Kenyan-gay-inmates-in-need-of-condoms-to-curb-hiv-infections-175430/

Musili L. \& Mbatia P. (2016) The status of HIV/AIDS management strategies in correctional settings in Kenya: A case study of Lang'ata Women and Kamiti Maximum Prisons. Sociology and Anthropology. 4 (4): 206211, 2016. http://www.hrpub.org

Namusonge, G. (2009). Business Statistics Concepts and Application. London: Lightning Source U.K Ltd.

Ogeto Ambrose (2009) The impact of prisons reforms on the inmate rehabilitation programs in Kenya: A case study of Kamiti and Langata Prisons.

Okie Susan (2007) Sex, drugs, prisons and H.I.V. The New England journal of medicine 356(2): 105-108. http://dx.doi.org/10.1056/NEJMP068277

Phillips. J. (2001) Cultural construction of manhood in prison. Psychology of men \& masculinity, 2 (1), 13-23.

Prisons of Offenders Act Cap 90

Rothstein M. \& Stannow L. (2009) Improving prison oversight to address Sexual Violence in Detention. American Constitution Society for Law and Policy

Rukwaru Mutea (2008) Anatomy of Crime. Eureka publishers. Meru.

Sexual Offences Act NO. 3 of 2006, Government Printers. Nairobi.

Sidhu, K. 1990. Methodology of research in education. New Delhi, India. Sterling

Siegel L. (2010) Criminology; Theories, Patterns and Typologies. $10^{\text {th }}$ ed. Wadsworth, Canada.

The World Book Encyclopedia. World book, Inc. Chicago.

Wright R. \& Miller M. (2005) Encyclopedia of Criminology (VOL 2) (H.P) Routledge. London.

Zweig J, Naser R, Blackmore J \& Schaffer M. (2006) Addressing Sexual Violence in Prison: A National Snapshot of Approaches and Highlights of Innovative Strategies, Final Report. U.S. Department of Justice. 